\title{
Estimation of Shelf Life of Bangkalan Zalacca (Salacca zalacca (Gaertner) Voss) Chips Using Vacuum Frying Technology and Aluminum Foil and PVC Plastic Packaging
}

\author{
Rosida, DF ${ }^{1, *}$, Permadi, B.S ${ }^{1}$, Sarofa, $\mathrm{U}^{1}$, Anggraeni, FT $^{2}$, Hapsari, $\mathrm{N}^{3}$ \\ ${ }^{\text {l} D e p a r t e m e n t ~ o f ~ F o o d ~ T e c h n o l o g y, ~ F a c u l t y ~ o f ~ E n g i n e e r i n g, ~ U n i v e r s i t y ~ o f ~ P e m b a n g u n a n ~ N a s i o n a l ~ V e t e r a n ~ E a s t ~ J a v a, ~}$ \\ Surabaya, Indonesia \\ ${ }^{2}$ Department of Informatics Technology, Faculty of Computer Science, University of Pembangunan Nasional \\ "Veteran" JawaTimur, Surabaya, Indonesia \\ ${ }^{3}$ Departement of Chemical Engineering, Faculty of Engineering, University of Pembangunan Nasional "Veteran" \\ JawaTimur, Surabaya, Indonesia \\ "Corresponding author. Email: dedin.tp@upnjatim.ac.id
}

\begin{abstract}
Bangkalan zalacca has a slightly sour and flat taste so it should be processed into zalacca chips. The problems that have arisen so far in the chips industry are crispness and packaging of chips that do not last long. For this reason, this study carried out research on the use of different types of packaging. Furthermore, the storage was carried out for 6 weeks. The purpose of this study was to determine the best treatment between the packaging type and storage time and estimation of shelf life of zalacca chips. The study used a Group Accord Design (RAK) with packaging group types (Aluminum foil and PVC) with a long storage factor (1 week, 2 weeks, 3 weeks, 4 weeks, 5 weeks and 6 weeks). The best treatment results are zalacca chips with aluminum foil packaging with a storage period of 1 week. with water content of $3.4130 \%$, ash content of $1.504 \%$; 24 fat content, 058\%, 3,518 peroxide number, FFA 0.164\%, Broken Power 7.872 N, aw 0.4, TPC (negative) with $0.74 \%$ tannin level. Estimation of shelf life of zalacca chips packed with aluminum foil was analyzed by the 3-week direct method while the shelf life of salak chips packed with PVC was analyzed by the 2-week direct method.
\end{abstract}

Keywords: zalacca, packaging, estimation, shelf life

\section{INTRODUCTION}

Zalaccais a fruit commonly found in Indonesia, one type of which is Bangkalan zalacca. The zalacca fruit has special characteristics such as brownish-yellow flesh, sweet-spicy, not stirred, lots of water so it is suitable to be applied in the form of chips [1]. Parameters that determine the quality of zalacca chips include color, aroma and taste, texture, nutrition, not easily rancid or durable. To maintain the quality of zalacca chips to remain guaranteed, salak chips need to be well packed [2]. In this study, making zalacca chip uding vacum frying method. Some of the advantages of the product if using a vacuum frying machine, including the results of fried chips do not change from the original color, the aroma and taste does not change from the original fruit or vegetable, no additional taste, (no flavor, no MSG, fried chips more crisp, machine material safe for food (food grade), the nutrient content in the product is not lost, the product from this machine is not easily rancid, so it is more tawless, but to be a long lasting aspect that needs to be considered in the production of salak chips is packaging [2].
Packaging that can be used for chips must have low permeability to gas and water vapor [3]. The conventional types of packaging that can be used include aluminum foil and PVC (Poly Vynil Chloride). Aluminum foil is a type of packaging consisting of sheets and laminates that have advantages such as lightweight, high density, the low transmission rate for water and oxygen and have hermetic, flexible, opaque properties [4]. PVC has a hard characteristic, is not easily damaged, stiff, clear and shiny, very difficult to penetrate water and has a low permeability to the gas so that it is suitable for packing food for a long time[5].

To determine the shelf life of zalacca chips it is necessary to conduct a study using the direct method based on deterioration during storage based on the detection of microbial changes accompanied by physical, chemical, sensory changes that are checked periodically [6].

\section{MATERIAL AND METHOD \\ Material And Tools}

The ingredients used include zalacca, cooking oil, aquadest, petroleum ether, $\mathrm{KI}, \mathrm{KOH}, \mathrm{Na}_{2} \mathrm{~S}_{2} \mathrm{O}_{3}, 1 \%$ starch, 
potato dextrose agar (Oxoid) and alcohol 96\%. The glassware, vacuum frying machines, thermometer, oven, furnace, cooling back, soxhlet, clamp, micropipette, filter paper, blender, condenser, analytic balance, desiccator, Erlenmeyer, Mohr pipette, stirrer, test tube, petri dish, incubator, funnel, freezer, spinner, knife.

\section{Methodology}

This research was carried out by using a Simple Group 1 Random Factor Design (RBD) with the treatment of groups of types of packaging, namely aluminum packaging and plastic packaging (PVC) and storage time ( 1 week, 2 weeks, 3 weeks, 4 weeks, 5 weeks and 6 weeks ) The data obtained were analyzed using variance analysis, to find out the differences between treatments used DMRT test with a level of 5\%.

\section{Product Making Procedure}

Peeled zalacca then separated from the seeds and split into two parts. Salak soaked in water for 10 minutes then stored the freezer for 2 days. The vacuum frying machine is prepared at $85{ }^{\circ} \mathrm{C}$, the pressure is $1 \mathrm{~atm}$ and the amount of oil is 10 liters. Salak is fried for 60 minutes until cooked and then removed and drain using more spin. Salak chips are packed with aluminum foil and PVC and stored at room temperature for 1-6 weeks [7].

Product Analysis

Zalacca fruit was analyzed for water content, fat content [8], tannin levels [9].

Salak chips were analyzed for water content, fat content [8], texture, organoleptic hedonic tests [10], Aw [11], Peroxide numbers, \% FFA [8], Total Plate Count.

\section{RESULTS AND DISCUSSION}

The analysis carried out in this study starts with the analysis of raw materials in the form of Bangkalan zalacca. Analysis of Bangkalan zalacca includes water content, fat content, and tannin. Analysis of Salak chips includes water content, fat, peroxide number, FFA, texture, Aw, TPC and organoleptic (taste, color, texture and aroma). equipment used includes indicators PP, acetic acid, Raw Material Analysis

Analysis of Bangkalan zalacca includes water content, fat content and tannin. The analysis results obtained were water content of $76.538 \%$, fat content of $0.421 \%$, and tannin of $1.34 \%$. Meanwhile, according to DKBM the water content in salak was $77.9 \%$, fat content was $0.40 \%$, and the salacca tannin content was $1.58 \%$ [12].

The analysis of Bangkalan zalacca as raw material shows that there are differences in the results of the analysis with the literature, the difference in water content can be caused by differences in temperature and drying method during the water content analysis process. According to Sitorus (2015) the difference in yield of water content due to the drying process of different raw materials can also affect the water content produced other than this, the age of harvest, where zalacca grows affects the water content produced.

Based on the results of the analysis of fat content that has been done, there are differences in the results between the analysis of raw materials with literature. Fat content in the raw material of Salak Bangkalan $(0.421 \%)$ is different from the literature. According to fat content in Bangkalan zalacca is $0.40 \%$. The difference in the results of the analysis can be due to the different types, age of harvest and the environment in which Salak grows and extraction factors of zalacca which can affect the amount of fat that is extracted. The difference in analysis results is due to the influence of differences in harvest age, variety and environmental conditions in which the raw materials grow [12]. Based on the results of the tannin content analysis that has been carried out, there are differences in the results between the analysis of raw materials and literature. Tannin levels in raw materials of Salak Bangkalan (1.34\%) different from the literature. Tannin levels in making zalacca were $1.58 \%$. The difference in the results of the analysis can be due to the different zalacca tannin analysis process, as well as the type, age of harvest and the environment in which zalacca grows, resulting in different levels of tannin.

\section{Product Analysis \\ Water content}

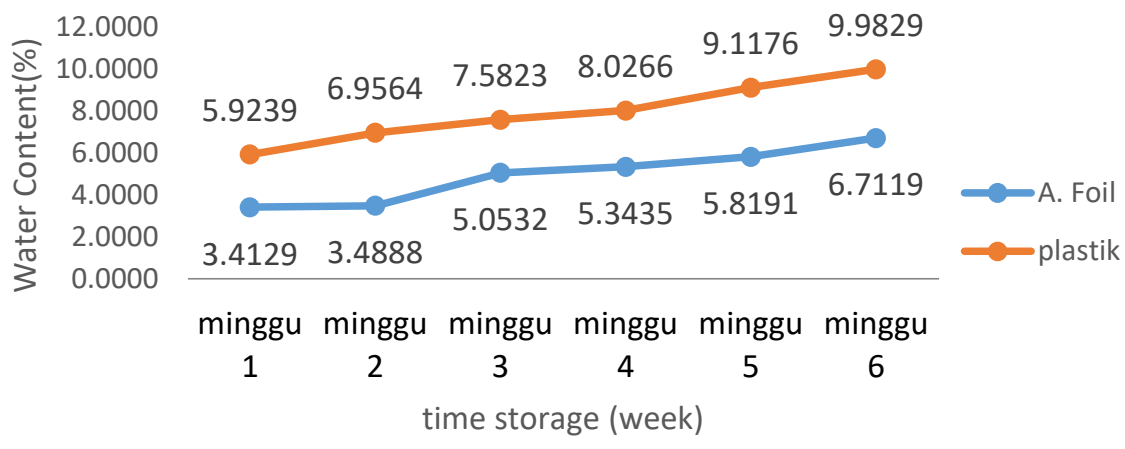

Figure 1. Relationship between differences in the type of packaging and the length of storage against the moisture content of zalacca chips. 
Figure 1. shows that the group type of packaging influences the water content of Salak chips, the longer the storage will increase the water content of Salak chips. The group of salak chips packed with PVC plastic produces the highest moisture content compared to aluminum foil packaging, this is due to the longer storage, the higher the water content and PVC type plastic has a high gas permeability and water vapor transmission rate and has a low density. Salak chips packed with PVC type plastic have high water content along with storage time.

This is supported [12], aluminum foil has a lower steam and oxygen transmission rate than PVC. The greater the value of the material density, the smaller the permeability of the material to gas and water vapor. The increase in water content in the product during storage is caused by the absorption of moisture from the environment where absorption occurs due to the permeability of the packaging and the surface area of the product to be able to capture water vapor [13].

Aluminum foil pack was found to be the most effective in controlling the moisture content of potato crisps compared to polyethylene bag which allowed the highest moisture build-up in the stored crisps. The product stored at $35{ }^{\circ} \mathrm{C}$ had significantly $(\mathrm{p}<0.005)$ higher increase in moisture content compared to those stored at 25 and $30{ }^{\circ} \mathrm{C}$. The difference in relative humidity was high and would be responsible for the high overall moisture content of crisps. The result was in agreement with those reported on storage changes [14].

\section{Peroxide Numbers}

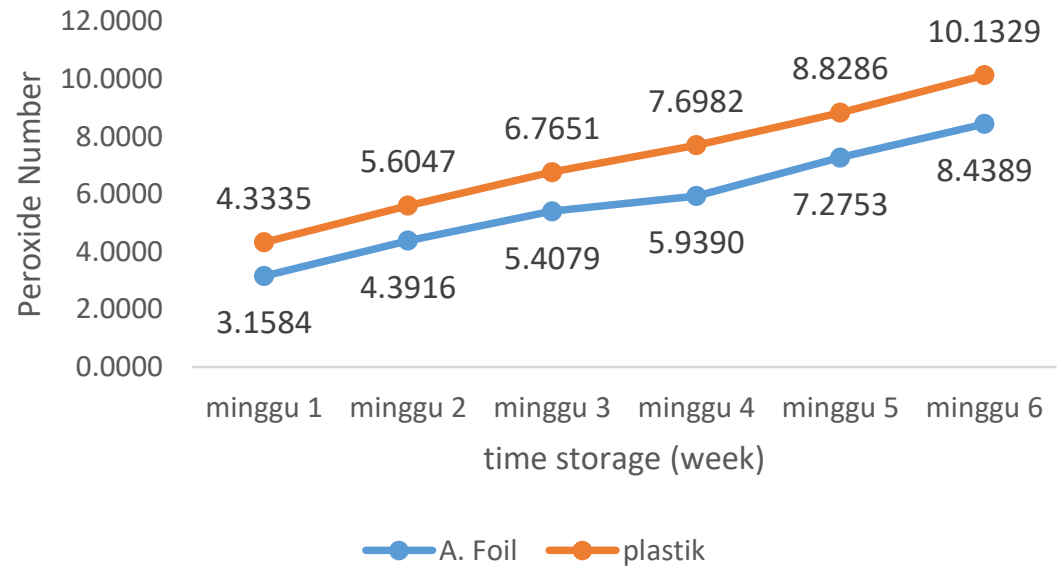

Figure 2. Relationship between differences in packaging type and storage time for peroxide Salak chips.

Figure 2. zalacca chips packed with PVC plastic packaging produce the highest zalacca peroxide chips compared to aluminum foil zalacca chips because this type of PVC plastic packaging has higher gas permeability than aluminum foil so that it is easily penetrated by oxygen gas which causes oxidized fat to form peroxide compounds so that the longer the storage the more peroxide compounds are formed and increase the peroxide number in zalacca chips.

The fat oxidation reactions form peroxide numbers [15]. Peroxide is used as an indicator of the level of oxidation in fats or oils. The presence of peroxide as an indication of oxidative damage to oil or fat. Peroxide number as one of the factors that influence the rate of fat oxidation in food is influenced by the appearance of peroxide compounds due to the reaction between free fatty acids and oxygen. Peroxide is the first result in the reaction oxidation. rancidity is formed by aldehyde and ketone fatty acids so the increase in peroxide is only an indicator that the fat contained in food will soon be rancid.

Generally, the aluminium foil pack was the most effective in controlling the formation of peroxides in potato crisps compared to polyethylene bags. The product stored at 35
${ }^{0} \mathrm{C}$ had significantly $(\mathrm{p}<0.005)$ higher increase in peroxides compare to that storage at 25 and $30{ }^{\circ} \mathrm{C}$ after 24 weeks of storage. The was no significant $(p>0.005)$ increase in peroxide value until 12 weeks of storage. The peroxide then accumulated steadily reaching the highest level of $7.4 \%$ in crisps stored at $35^{\circ} \mathrm{C}$ [16].

Figure 3. shows that the type of packaging influences the FFA of zalacca chips, the longer the storage will increase the level of FFA, this is because zalacca chips will be hydrolyzed during storage thus increasing the level of FFA due to the fat that turns into free fatty acids. The water vapor that enters the packaging will increase the level of FFA because water vapor can cause hydrolysis reactions which can increase the FFA.

Zalacca chips packed using PVC plastic packaging produce chips with the highest FFA content compared to aluminum foil zalacca chips. This is because PVC plastic packaging has high permeability to water vapor which is easily penetrated by water vapor which causes increased water content in the material. Water will hydrolyze the oil and cause the breakdown of the carbon chain in the oil to form free fatty acids so that the longer the storage the higher the level of FFA. This is supported [17], the amount 
of gas and water vapor that can penetrate into the packaging material is related to the O2TR value and WVTR packaging material. This type of packaging has the ability to inhibit the entry of different water vapor, so there is a difference in the amount of free fatty acids formed by hydrolysis reactions. The hydrolysis reaction is related to the increase in water content in chips which causes the formation of free fatty acids. This is supported by [18], which states that during storage of FFA levels on carrot chips packed using aluminum foil will increase. FFA levels of carrot chips during 56 days of storage increased from $0.2 \%$ to $1.01 \%$.

Free fatty acids are known to result from fat or oil breakdown due to either enzyme activity and oxidation or the use of high frying temperatures. The accumulation of free fatty acids is normally accelerated by storage at high temperatures and in the presence of light or water. Therefore, total fatty acid changes have been found to be a useful tool for determining optimum frying and storage studies [19].

FFA (Free Fatty Acid)

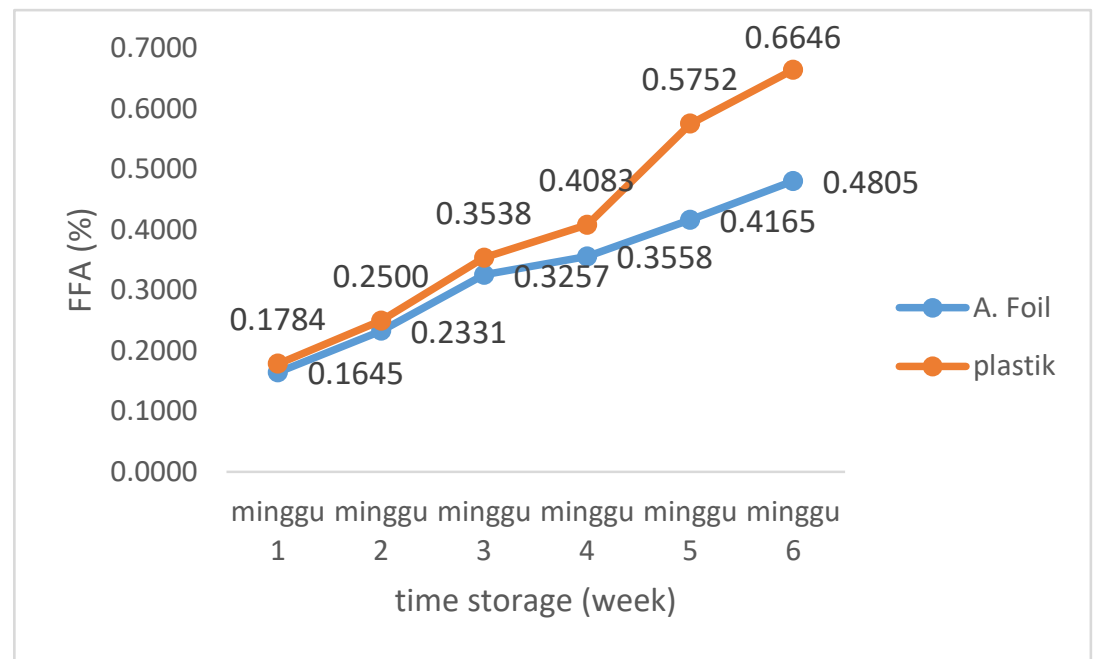

Figure 3. Relationship between differences in packaging type and storage time for FFA Salak chips.

\section{Crunchiness (Broken Power)}

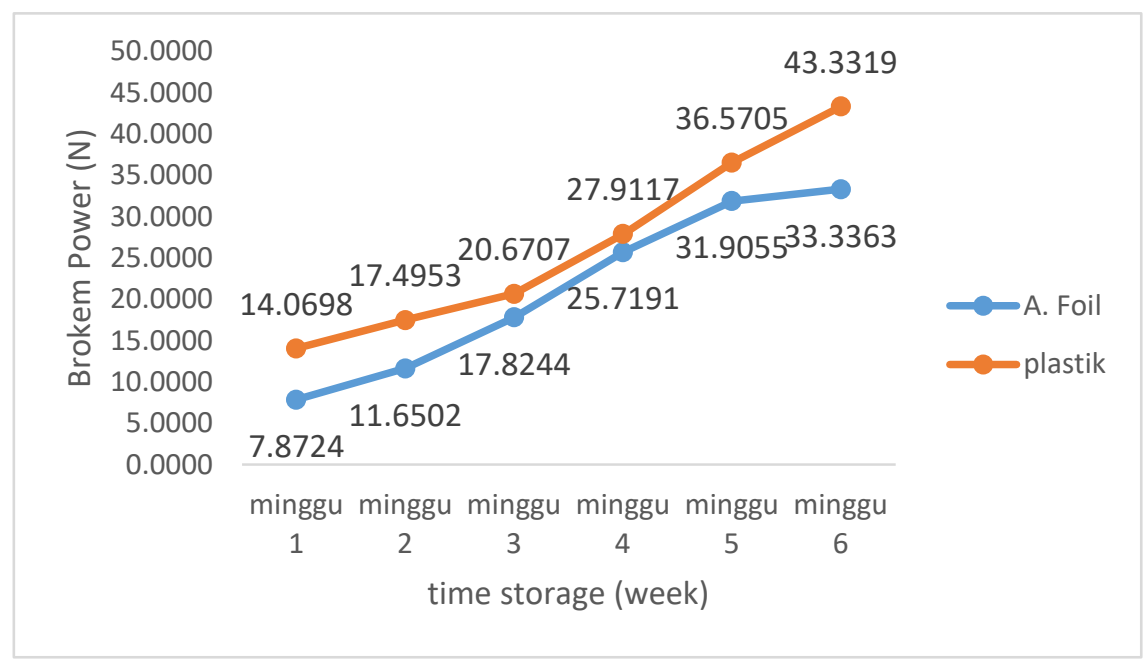

Figure 4. Relationship between differences in packaging type and storage time against fracture of Salak chips.

Figure 4. Zalacca chips packed with PVC plastic produce the highest broken power compared to aluminum foil packaging where the higher the breaking strength, the more the texture value (not crispy) decreases, this is due to the PVC plastic packaging having a relative permeability to the water vapor transmission rate high and has a low density so that it is easily penetrated by water vapor, causing a broken power of zalacca chips which are packed using higher PVC plastic due to increased product moisture content during storage. The higher the value of 
water content will cause a high value of broken power, which means that the value of the texture (not crispy) decreases. This is in accordance with study [20], which states that during storage there will be a decrease in crispness and texture of stored chips due to an increase in moisture content during storage, the product will absorb water from the environment, the less dense an ingredient is the easier absorption water so the texture becomes not crisp.

The longer the storage of chips the higher fracture power, which causes a decrease in texture (not crispy). This can be caused by the water content in chips which increases during storage and the water content can cause the value of the broken power to be higher, resulting in crispy chips.
This is following the opinion of Siregar (2004). The more water it contains, the more crispy the chips will be.

Packaging type significantly $(p \leq 0.05)$ influence the amount of ascorbic acid retained within a given storage period. There was no significant $(p>0.05)$ variation of the vitamin content within 8 weeks of storage in crisps packaged in polyethylene bags and aluminum foil packs. However, after 8 weeks of storage significant $(p<0.05)$ reduction of ascorbic acid was noted in all the cultivars. Crisps packaged in aluminum foil pack retained a higher level of ascorbic acid (78\%) compared to those in polyethylene bags which retained $58 \%$ after 24 weeks of storage [21].

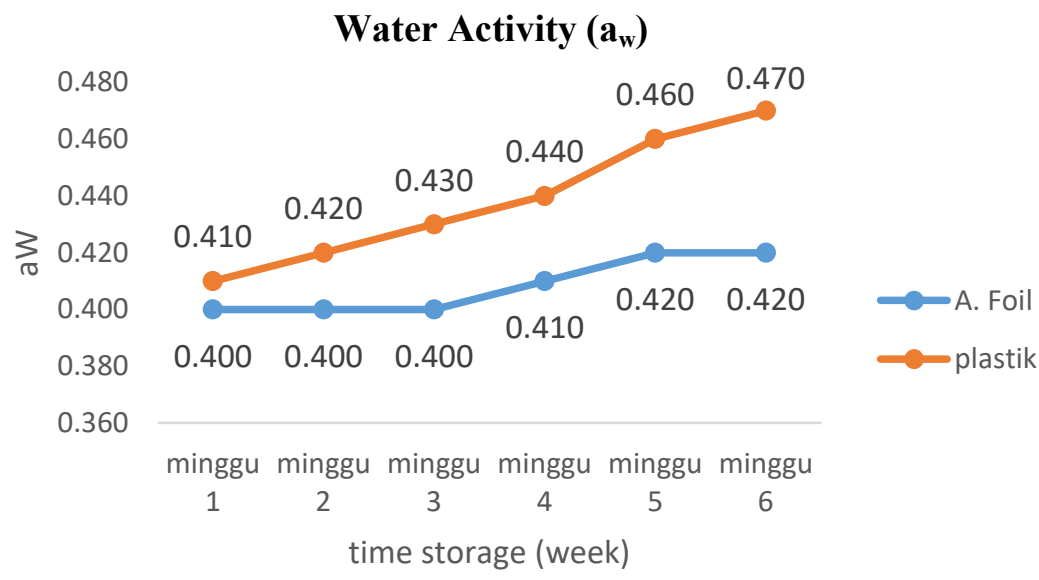

Figure 5. Graph between the different types of packaging and the length of storage against aw Salak chips.

Figure 5. shows the longer storage period the higher the aw value is due to the longer storage period and the higher the permeability value of the packaging to water will cause aw to increase. During storage, the product absorbs environmental water so that the aw content increases with increasing water content of the product. This is supported by [22], who stated that during storage can increase the amount of bound water which will be followed by increased water activity (aw).

This was supported by [23], who stated that banana chips packed using PP then stored for 120 days experienced an increase from 0.16 to 0.60 . An increase in water activity showed that the water vapor was able to permeate from outside. The level of nano clay, compatibilizer and film thickness influenced the water vapor permeability. At lower level oh nanoclay (2\%) and compatibilizer (5\%) and higher level of thickness (100-120 mm), due to uniform scattering of nanoclay in the polymer matrx, more tortous path is cretaed for water vapor molecule to travel in the film [23].

\section{TPC (Total Plate Count)}

Total plate count (TPC) is a method of calculating the number of bacterial colonies contained in a product that grows on agar media at a set temperature and time. According to Quantitative analysis of microbiology on food ingredients is important to determine the quality of these foods [24]. Several ways can be used to calculate or measure the number of microorganisms in a suspension or material, one of which is the calculation of the number of cells using the count cup (TPC) method.

Table 1. shows the longer storage period the higher bacteria value. This is because the longer the storage period and the higher permeability of the packaging to water and oxygen, the more water is bound to the product so that it increases the level of salak chips, allowing microbes to grow and develop. This is supported by [25], which states that the total number of microbes increases with the length of the storage period. The microorganisms detected by the TPC test can be bacteria, molds, or yeast. Types of microorganisms or microbes commonly found in food in the form of powder are molds. The cause of the increasing number of microorganisms in potato chips can be caused by the presence of mold. Mold is a microorganism that belongs to the group of fungi. Molds are commonly found in dry foods. Foods that have low aw are susceptible to mold contamination. 
Besides aw, $\mathrm{pH}$, nutrient content of food, storage, and processing temperatures, the availability of oxygen in these foods can also be a cause of microbial growth in food. An improper packaging process will cause the entry of mold from the air containing mold spores during processing as well as from the food wrapping plastic itself [26].

The initial total plate count was recorded as $1.9 \log \mathrm{cfu} / \mathrm{g}$ which increased steadly with storage period. The moisture content anf $=\mathrm{d}$ water activity of banana chips and OTR and
WVTR of the packaging film influenced the microbial growth. The films of treatment $\mathrm{E}$ and $\mathrm{N}$ exhibited lower OTR and WVTR due to characteristic scattering of nanoclay inside the polymer matrix which resulted in lower moisture content and water activity of banana chips. Hence, the microbial growth was lower in the films of treatment $\mathrm{E}$ and $\mathrm{N}$. The plate count was observed maximum for the control sample however, lowest microbial growth was recorder for treatment $\mathrm{N}$ [23].

Table 1. TPC values with group types of packaging and long-term treatment of salak chips

\begin{tabular}{|l|c|c|c|}
\hline \multicolumn{2}{|c|}{ Independent variabel } & \multicolumn{2}{c|}{ TPC } \\
\hline Type of packaging & Storage time & CFU/ml & Log CFU/ml \\
\hline Alumunium Foil & 1 week & - & - \\
\hline Alumunium Foil & 2 week & - & - \\
\hline Alumunium Foil & 3 week & $0,9 \times 10^{4}$ & 3,9542 \\
\hline Alumunium Foil & 4 week & $6,4 \times 10^{4}$ & 4,8062 \\
\hline Alumunium Foil & 5 week & $2,3 \times 10^{6}$ & 6,3617 \\
\hline Alumunium Foil & 6 week & - & - \\
\hline Plastik (PVC) & 1 week & - & - \\
\hline Plastik (PVC) & 2 week & $1,2 \times 10^{4}$ & 4,0792 \\
\hline Plastik (PVC) & 3 week & $3,1 \times 10^{4}$ & 4,9590 \\
\hline Plastik (PVC) & 4 week & $1,14 \times 10^{5}$ & 5,0569 \\
\hline Plastik (PVC) & 5 week & $1,16 \times 10^{7}$ & 7,0645 \\
\hline Plastik (PVC) & 6 week & \\
\hline
\end{tabular}

\section{Estimated Age Save Direct Method Method}

The most direct method is applied by placing the product in a storage room with certain conditions for a certain time (more than the estimated shelf life). Products are then checked regularly to see changes that might occur (both quality and safety) which include sensory evaluation, physical and chemical testing. The results are as follows in Table 2 .
Table 2. shows that the Aluminum foil packaging fulfills all test parameters with storage time 1-4 on chemical testing, while on PVC packaging zalacca chips Aluminum foil packaging meets all test parameters with 1-2 storage times in chemical testing. This shows that the best shelf life is based on chemical tests, microbes, and sensory evaluation is 3 weeks or for Aluminum foil packaging, while for PVC packaging, the best conditions according to SNI are 1 week of storage.

Table 2. Shelf life Analysis Table

\begin{tabular}{|c|c|c|c|}
\hline \multirow{2}{*}{$\begin{array}{c}\text { Parameter } \\
\text { Chemical Testing }\end{array}$} & \multirow{2}{*}{ SNI } & \multicolumn{2}{|c|}{ Result } \\
\hline & & A.Foil & PVC \\
\hline Water Content & Maks. 5-6\% & Week 1-5 qualify of SNI & Just first week qualify of SNI \\
\hline Ash Content & Maks. 3\% & Week 1-6 qualify of SNI & Minggu 1-6 memenuhi SNI \\
\hline Fat Content & Maks. 25\% & Week 1-6 qualify of SNI & Minggu 1-6 memenuhi SNI \\
\hline Peroxide Number & Maks. 10 & Week 1-6 qualify of SNI & Minggu 1-5 memenuhi SNI \\
\hline FFA & Maks 1\% & Week 1-6 memenuhi SNI & Minggu 1-6 memenuhi SNI \\
\hline
\end{tabular}

\section{CONCLUSION}

Zalacca chips packed with aluminum foil for 3 weeks were the best results with water content of $3.4130 \%$, fat content $24,0584 \%$, peroxide number 3,5184, FFA 0,1645\%, Broken Power 7,8724 N, Aw 0,4, TPC (negative) with an average organoleptic value of 3,8 , aroma 4,6 , texture 4,9 and taste 4,55 with tannin level $0,74 \%$.

Estimation of shelf life of salak chips packed with aluminum foil analyzed by 3 -week direct method is the best package while the shelf life of salak chips packed with $\mathrm{PVC}$ is analyzed by direct method 1 week. 


\section{ACKNOWLEDGMENT}

Thank you to the directorate of research and community service at the directorate general of higher education who has funded the regional superior development program (PPUD) for 2017-2019.

\section{REFERENCES}

[1] Fatimah, S and Sucipto. 2011. Kinship Relations of Eleven Types of Salak (Salacca zalacca (Gaertner) Voss) Bangkalan Plants Based on Isoenzyme and Morphological Analysis. National Seminar on Integrated Agricultural Reform Towards Food Sovereignty. Aglicultural faulty trunojoyo university. Bangkalan.

[2] Sudjud, H. R. 2000. Studying the effect of temperature and time of vacuum frying on physical and organoleptic characteristic of cemepdak fruit (Artocarpus integer (Thunb) Merr). Agliculture technology faculty IPB, Bogor.

[3] Enggar, E. 2009. Vacum Fried Snack. https://ptp2007.wordpress.com/2008/07/11/vacuu m-fried-snack/. That accessed at 21 st December 2018.

[4] Nurhudaya. 2011. Engineering of vacum frying and packaging of mentawai durian chips. Agliculture faculty IPB. Bogor.

[5] Suyitno. 1990. Packaging materials. PAU. UGM. Yogyakarta.

[6] Asiah, N., Larasati, C and Wahyudi, D. 2018. Estimation of food product shelf life. UB Press. Universitas Bakrie.

[7] Romadhon, F. A. I. 2017. Effect of freezing as an introduction to the crispness of zalacca chips using a vacuum fryer. Malang. Brawijaya University.

[8] AOAC. 2005. Official Methods of Analysis, 15th Ed. Associcition og Official Analytical Chemists, Inc.Vigrinia, USA.

[9] Chanwitheesuk, A, Teerawutgulrag, A.and Rakariyatham, N. 2004. Screening of Antioxidant Activity and Antioxidant Compounds of Some Edible Plants of Thailand. Food Chemistry. 92, 491-497. 2004.

[10] Rahayu, W.P. 2001. Organoleptic. Nutrition and food technology department. Food technologi faculty. IPB. Bogor.

[11] Ranganna, S. 1977. Manual Analysis of Fruit and Vegetables Product. Tata Mc Graw Hill Publishing Co. Limited. New Delhi.
[12] Hidayati, N. 2013. Physical and chemical properties of salak pondoh in sleman regency. Agros journal Vol. 15 No.1, 166-173. 2013.

[13] Handayo, M.P. 2010. Oxidation of dry oven dry beef jerky during storage. Production science and animal husbandry technology department. Animal husbandry faculty. IPB. Bogor.

[14] Vanhanen, L.P. and Savage, G.P. 2006. The use of peroxide value as a measure of quality for malnut flour stored at five different temperatures using three different types of packaging. Food chem, 99: 64-69.

[15] Ketaren, S. 1989. Introduction to food oil and fat technology. Jakarta: Indonesia university

[16] George, O.A., Michael, W. O., Jasper, K. I., and Jackson, N. K. 2011. Effect of packaging and storage temperature on the shelf life crisps from four kenyan potato cultivars. American journal of food technology 6 (10): 882-892

[17] Murni, A., Herla, R., Ridwansyah. 2017. Estimating the shelf life of potato onion crackers by the acceleration method based on the critical water content approach. Food engineering and agriculture journal. Vol.5 No. 1 Th. 2017.

[18] Putra, M.R.P. 2010. Estimated shelf life of carrot chips (Daucus carota L) in aluminium foil packaging with acceleration method. Agliculture technology faculty IPB. Bogor.

[19] Ullah, J., Hamayoun, M., Ahmad, T., Ayub, M. And M. Zafarullah. 2003. Effect of light, natural and synthetic antioxidant on stability of edible oil and gfats. Asian J. Plant Sci., 2: 1192-1194

[20] Istanti. 2005. Effect of storage duration on broom sweep crackers characteristics. Fisheries and marine faculty IPB, Bogor.

[21] Abong, G.O., Okoth, M. W., Imugi, J. K., and Kabira, J.N. 2011. Losses of ascorbic acid during storage of fresh tubers, frying, packaging, and storage of potato crisps from four kenyan potato cultivars. American journal of foood technology 6 (9) : 772-780

[22] Arizka, A.A and Joko, D. 2015. Changes in tea moisture and water content during storage at different temperature and packages. Food technology application journal.

[23] Manikantan, M.R., Rajiv, S., Kasturi, R. And Varadharaju, N. 2012. Storage stability of banana chips in polypropylene nano composite packaging film. J food sci technol. 
[24] Fardiaz. 2004. Food microbiology analysis. PT. Raja Grafindo Persada : Jakarta.

[25] Dinaningsih, E. 2016. Duration of storage of fried radish crackers from various mocaf and radish formulations on chemical and organoleptic physicochemical risk. Reporsitory of Semarang university.

[26] Danarsi, C.S. 2016. Effect of storage duration on microbiological quality of complementary food for mother's milk (MP-ASI) instant porridge with substitution of fishmeal flour and yellow pumkin flour. Research article. Nutrition science major madicine faculty of Diponegoro University.

[27] Manikantan, M.R. Arumuganathan, T., Indu, R.C and Varadharaju. 2016. Storage Stability of Sugarcane Juice in Polypropylene-Based. Sugar Tech DOI 10.1007/s12355. 2016 